\title{
QUANTITATIVE AND QUALITATIVE ANALYSIS OF PROTEINS IN RAT PERIPHERAL NERVES PREDEGENERATED FOR 7 DAYS
}

\author{
Marita Pietrucha-Dutczak, Wieslaw Marcol, Dariusz Gorka, Beata Golka, \\ Katarzyna Kotulska, Joanna Lewin-Kowalik
}

\author{
Department of Physiology, Medical University of Silesia, Katowice, Poland \\ e-mail:Vie@alpha.net.pl
}

Received: October 26, 2006; Accepted: November 5, 2006

Key words: Electrophoresis/Predegeneration/Regeneration/Submicrosomal fraction

Objectives: In contrast to peripheral nerves, central neurons do not regrow spontaneously after injury. Our previous studies showed that transplantation of degenerating peripheral nerves or their extracts can induce regeneration in the injured central nervous system. Non-predegenerated nerves show much weaker neurotrophic activity. The aim of the present work was to examine quantitatively and qualitatively the protein composition of rat sciatic nerve extracts.

Material and Methods: The experiments were carried out on male Wistar C rats. Distal fragments were collected immediately after transection or after 7 day-long predegeneration. The nerves were homogenized, centrifuged and ultracetrifuged. Extracts were analyzed by means of two-dimensional electrophoresis.

Results: The two-dimensional electrophoresis showed 69 protein subfractions with isoelectric points ranging from 4.2 to $7.0 \mathrm{pH}$ and molecular weight ranging from $13.5 \mathrm{kDa}$ to $335.4 \mathrm{kDa}$ in extracts obtained from nonpredegenerated nerves. In predegenerated nerve extracts 114 subfractions with isoelectric points ranging from 4.2 to $7.4 \mathrm{pH}$ and molecular weight from $21.1 \mathrm{kDa}$ to $335.4 \mathrm{kDa}$ were found. Fractions: $25.5 \mathrm{kDa}, 31.6 \mathrm{kDa}, 36 \mathrm{kDa}, 38.4 \mathrm{kDa}, 42.4 \mathrm{kDa}$, $46.6 \mathrm{kDa}$, and $50.5 \mathrm{kDa}$ showed significant increase and two fractions: $68.5 \mathrm{kDa}$ and $335.4 \mathrm{kDa}$ demonstrated significant decrease in the number of subfractions in predegenerated nerves. Fractions $160.8 \mathrm{kDa}, 236.1 \mathrm{kDa}$, and 5 fractions below $21.1 \mathrm{kDa}$ were present only in extracts from non-predegenerated nerves.

Conclusions: In conclusion, the results of our study demonstrate that the most intense changes in protein composition in degenerating nerves take place in low molecular weight fractions.

\section{INTRODUCTION}

It is proven that the damaged neurons of the central nervous system (CNS) of adult mammals, in contrast to peripheral nervous system, do not have the capacity for spontaneous and successful regrowth. The inability of adult CNS neurons to regrow after injury do not stem from an intrinsic deficit of the neuron, but rather from a characteristic feature of the enviroment of damaged neurons that prevent successful regeneration. Recently it has been suggested that adult CNS neurons can regrow if the enviroment of central nervous system is modified suitably. Thus neurobiologists try to introduce into CNS regeneration, stimulators such as neurotrophic factors, substances blocking growth inhibitors, genetically modified cells, tissue extracts, fetal neurons, Schwann cells, fibroblasts, central glia, and olfactory epithelia or they manipulate intracellular signalling and modulate the immune response to obtain regrowth of damaged neurites ${ }^{10,14,35,39}$.

Implantation into injured parts of CNS fragments of peripheral nerves or extracts from such nerves is another strategy for inducing regeneration ${ }^{1,9,20,24-26,28,29,32}$. It is known that distal part of injured peripheral nerve plays crucial role in nerve regeneration. Our previous studies revealed that purified extracts obtained from predegenerated nerves stimulate outgrowth of damaged neurites in both PNS and CNS ${ }^{12,24-26,28,29,31}$. Our group found that the neurotrophic activity of the above extracts depends on the predegeneration period and reaches three maxima at the $7^{\text {th }}, 28^{\text {th }}$ and $35^{\text {th }}$ day after nerve transection. The greatest neurotrophic activity had fractions obtained from nerves predegenerated for 7 days $^{24-26,28}$. Moreover it is possible to intensify their neurotrophic effect by extraction proteins of molecular weight from 10 to $100 \mathrm{kDa}$ from the entire extract [in press - Neurotrophic activity of extracts from distal stumps of predegenerated peripheral rat nerves varies according to molecular mass spectrum ${ }^{5}$. This forms the rationale for selecting these extracts for further investigation.

The aim of the present work was to analyze quantitative and qualitative changes in protein composition of predegenerated peripheral nerves by means of two- dimensional gel electrophoresis.

\section{MATERIALS AND METHODS}

The experiment was carried out on male Wistar C rats, weighing 200-220 g according to the Polish Animal Protections Laws and the European Union Directives. All procedures were approved by the local Ethics Committee. The animals were housed in individual cages and received 
a standard diet and water ad libitum. Forty animals were used to prepare postmicrosomal fractions from nonpredegenerated and predegenerated nerves (twenty animals for each kind). In our experiments we analysed the protein composition of extracts by means of two-dimensional gel electrophoresis.

\section{Postmicrosomal Fraction Preparation}

The animals were deeply anesthetized with a chloral hydrate intraperitoneal injection ( $420 \mathrm{mg} / \mathrm{kg}$ body $\mathrm{wt}$ ). The right sciatic nerves were cut near the hip joint. Seven days later, the rats were sacrificed by decapitation and the distal stumps of cut sciatic nerves and whole left intact sciatic nerves were dissected and stored in cold Ringer solution for mammals. Nerves transected 7 days earlier served as a source of postmicrosomal fractions for the PD group, whereas fraction in the NPD group was obtained from intact nerves. Subsequently, nerves were homogenized (Ultrasonic Processor GE 50, Aldrich, USA) in a buffer ( $\mathrm{pH}$ 6.4) consisting of $0.1 \mathrm{M}$ morpholinoethane sulfonic acid (MES); 1mM ethyleneglycol bis (2-aminoethylether)-N,N,N',N'-tetraacetic acid (EGTA); $0.1 \mathrm{mM}$ methylenediaminetetraacetic acid (EDTA) (all Serva, Heidelberg, Germany), using $2 \mathrm{ml} / 1 \mathrm{~g}$ nerve tissue. Homogenates were filtered through cotton gauze and filtrates were sedimented by centrifugation at $700 \mathrm{x}$ g for $10 \mathrm{~min}$. Supernatants were centrifuged at $20000 \mathrm{x} \mathrm{g}$ for $10 \mathrm{~min}$ and then ultracentrifuged at $105000 \mathrm{x}$ g for 120 min to obtain postmicrosomal fractions. All preparation procedures were carried out at $0{ }^{\circ} \mathrm{C}$ in the presence of $1 \mathrm{mM}$ phenylmethylsulfonyl fluoride (PMSF) (Serva) as a protease inhibitor. Total protein concentration in the final extracts was determined by the method of Bradford ${ }^{3}$.

\section{Two-dimensional electrophoresis}

Postmicrosomal fractions were analysed by two-dimensional electrophoresis according to the method of O'Farrell ${ }^{34}$. This method consists of two stages: isoelectric focusing and SDS-PAGE-electrophoresis.

\section{Isoelectric focusing}

Isoelectric focusig separated proteins according to their isoelectric points. Glass tubes were filled with urea gel [9 M urea (POCH), 3.77\% acrylics (Sigma), $0.22 \%$ bis-acrylamid (Sigma), $0.5 \%$ nonidet (Sigma), 25 M CHAPS (Sigma), 2 \% Pharmalyt (Pharmacia)] with a $\mathrm{pH}$ gradient from 4.2 to 7.4 (archieved by means of 3-10 Pharmalyte). Gels were subjected to pre-focusing (preliminary focusing) lasting $45 \mathrm{~min}$. Then $100 \mu \mathrm{l}$ of protein fraction was placed at the top of the tubes. One of the tubes was left "empty" (without protein) and used for preparation of the standard curve for $\mathrm{pH}$ estimation. Proper focusing was performed for 18 hours at $300 \mathrm{~V}$.

\section{SDS-PAGE-electrophoresis}

After focusing, the gel "noodles" were removed and stained in Coomasie Brillant Blue R-250 [0.1\% Coomasie Brillant Blue R-250 (Serva), $10 \%$ acetic acid (POCH), $40 \%$ methanol $(\mathrm{POCH})]$ for $15 \mathrm{~min}$ and were then joined with SDS-polyacrylamide gels with help of $1 \%$ agarose (Serva). We applied $8 \%$ separating gel and $5 \%$ concentrating gel. Electrophoresis was performed for 18 hours at $300 \mathrm{~V}$ followed with $400 \mathrm{~V}$ for 1 hour. After electrophoretic resolution gels were fixed and silvered according to the method of Wray ${ }^{41}$. Gels were photographed, molecular weights of proteins were estimated by the Southern method $^{38}$. Ten resolutions for each group were performed. For statistical analysis we used the Student t-test (we compared the number of the subfraction in protein fractions identified on electrophoregram of extracts from predegenerated nerves with nonpredegenerated). The level of significance was set at $\mathrm{p}<0.05$.

\section{RESULTS}

In extracts obtained from predegenerated nerves the total protein concentration was significantly higher $(\mathrm{p}<0.05)$ than in the extracts from nonpredegenerated nerves. (Tab. 1)

The two-dimensional electrophoresis showed 28 protein fractions of different molecular weights (from $13.5 \mathrm{kDa}$ to $335.4 \mathrm{kDa}$ ) containing 69 protein subfractions with pI ranging from 4.2 to 7.0 in extracts obtained from nonpredegenerated nerves. The widest range applies to the $68.5 \mathrm{kDa}$ fraction, with pI 4.4-7.0. (Tab. 2)

In extracts obtained from predegenerated nerves 21 protein fractions and 114 subfractions were present, with pI ranging from 4.2 to 7.4 and molecular weight from $21.1 \mathrm{kDa}$ to $335.4 \mathrm{kDa}$. Widest range showed fraction 42.4 kDa (4.4-7.4), whereas the narrowest - 335.4 kDa (4.6-4.9). (Tab. 3, Fig. 1) Seven fractions $25.5 \mathrm{kDa}$; $31.6 \mathrm{kDa} ; 36 \mathrm{kDa} ; 38.4 \mathrm{kDa} ; 42.4 \mathrm{kDa} ; 46.6 \mathrm{kDa}$; $50.5 \mathrm{kDa}$ and showed significant increase in the number of subfractions as compered to extracts from nonpredegenerated nerves (Fig. 1 and 2). Only two fractions - 68.5 kDa and 335.4 kDa demonstrated significant decrease in the number of subfractions at the $7^{\text {th }}$ day after transection. Fractions $160.8 \mathrm{kDa} ; 236.1 \mathrm{kDa}$ and fractions below $21.1 \mathrm{kDa}$ (13.5 kDa; $16.2 \mathrm{kDa} ; 17.2 \mathrm{kDa} ; 18.6 \mathrm{kDa}$; $20.0 \mathrm{kDa})$ were absent in extracts from predegenerated nerves.

On the basis of above observations it can be concluded that the most intensive changes in protein composition

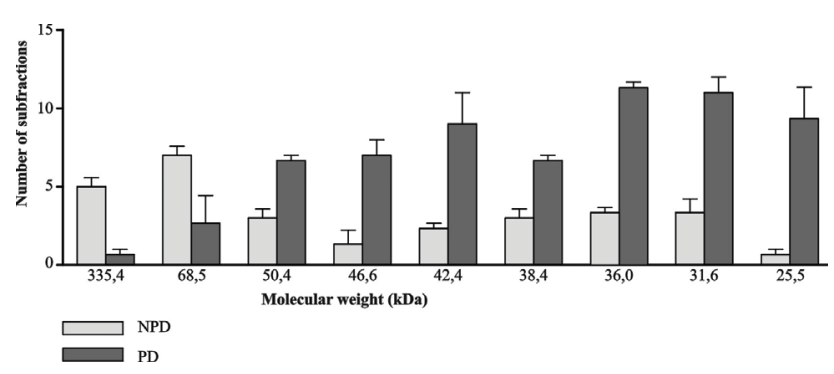

Fig. 1. Histogram showing a number of subfractions with different isoelectric points in nonpredegenerated and prenegenerated rat sciatic nerves. 


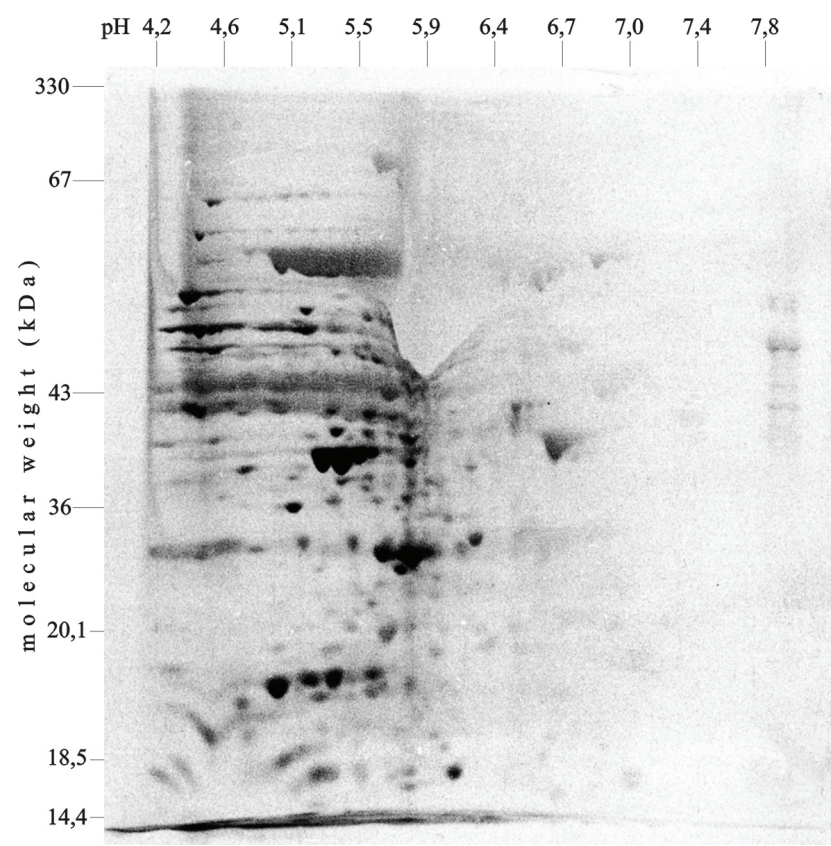

Fig. 2. 2D-PAGE electrophoretogram of proteins from predegenerated distal stumps of rats' sciatic nerves.

of postmicrosomal fractions were observed in proteins between $25.5 \mathrm{kDa}$ and $68 \mathrm{kDa}$ in extracts from predegenerated nerves.

\section{DISCUSSION}

Our results demonstrate that a process of 7-days predegeneration of peripheral nerves leads to intensive changes in protein composition in the distal segment. We know that extracts from distal segments of peripheral nerves predegenerated for 7 days show the strongest neurotrophic activity on the damaged hippocampus in adult rats ${ }^{24,25,27,28}$. Moreover it is possible to intensify their neurotrophic effect by extraction from the entire extract proteins of molecular weight from 10 to $100 \mathrm{kDa}$ (in press - Neurotrophic activity of extracts from distal stumps of predegenerated peripheral rat nerves varies according to molecular mass spectrum.).

After electrophoretic examination of extract from predegenerated nerves we observed a significant increase in the number of subfractions for fractions $25.5 \mathrm{kDa}$, $31.6 \mathrm{kDa}, 36.0 \mathrm{kDa}, 38.4 \mathrm{kDa}, 42.4 \mathrm{kDa}, 46.6 \mathrm{kDa}$ and $50.4 \mathrm{kDa}$ as compared to the extract from nonpredegenerated nerves. (Tab. 2 and 3; Fig. 1) Which of this fraction or combination of several fractions could participate in the neurotrophic activity?

The active subunit $\beta$ of NGF has a molecular weight about $26 \mathrm{kDa}^{28}$. Perhaps in the mixture of subfractions from predegenerated extract it is NGF which plays an essential function in neurotrophic processes but probably it is not only factor. In an in vivo experiment we showed that introducing fractions below $30 \mathrm{kDa}$ from predegener-
Table 1. Total protein concentration ( $\mathrm{mg} / \mathrm{g}$ tissue) in postmicrosomal fractions from the distal stumps of nonpredegenerated (NPD) and predegenerated (PD) rat sciatic nerves.

\begin{tabular}{|l|c|c|}
\hline & NPD $(\mathrm{n}=10)$ & PD $(\mathrm{n}=10)$ \\
\hline $\begin{array}{l}\text { PROTEIN } \\
\text { CONCENTRATION } \\
(\mathrm{mg} / \mathrm{g} \text { tissue })\end{array}$ & $1.310 \pm 0.810$ & $3.210 \pm 2.979$ \\
\hline
\end{tabular}

ated nerves into damaged hippocampus the outgrowth of neurites was not as intensive as in the case of complete extracts $^{22}$.

Another interesting protein with a molecular weight of about $25 \mathrm{kDa}$ is $\mathrm{Bcl}-2$. Bcl-2 is the main controller of apoptosis in mammals, especially important in the nervous system $^{8}$. Bcl-2 protein is known to prevent neurons from apoptosis induced by many different factors, including axotomy, but thus far, its role in axon regeneration has not been established. However our previous study suggested that Bcl-2 is important for the neurotrophic activity of peripheral nerve grafts during optic nerve regeneration ${ }^{21}$.

Comparing electrophoretograms from predegenerated nerves with nonpredegenerated ones we noticed lack of the protein fractions below $21.1 \mathrm{kDa}(13.5 \mathrm{kDa}, 16.2 \mathrm{kDa}$, $17.2 \mathrm{kDa}, 18.6 \mathrm{kDa}, 20.0 \mathrm{kDa})$. We assume that a reason for the absence of these proteins is degradation of the myelin during Wallerian degeneration induced by the nerve injury. Components of the myelin sheet have very similar molecular weights - protein $\mathrm{A}_{1}$ - $18.4 \mathrm{kDa}, \mathrm{MBP}$ - $18 \mathrm{kDa}$ and $\mathrm{P}_{1}-15 \mathrm{kDa}$. The proteins are degraded (resorpted) by macrophages and this might be the reason that they are absent in electrophoretograms. Perhaps among fractions with molecular weights from $25.5 \mathrm{kDa}$ to $50.4 \mathrm{kDa}$ which increases the number of subfractions, there are some proteins building the peripheral myelin sheet. The molecular weight of the main protein in peripheral myelin $\mathrm{P}_{0}$ is $30 \mathrm{kDa}$ and LG1 - $25 \mathrm{kDa}$, as well as Wolfgram proteins - $52 \mathrm{kDa}$ and $55 \mathrm{kDa}$ and two izoforms of CNP - $46 \mathrm{kDa}$ and $48 \mathrm{kDa}^{11,16,18,21,22,39}$. Myelin sheet proteins do not possess neurotrophic properties but as components of newly formed myelin, they might be able to influence the remyelinization process of regenerating nerve fibres.

A protein which has aroused our interest is apolipoprotein $\mathrm{E}$ with a molecular weight of about $37 \mathrm{kDa}$ and which participates in lipid and cholesterol metabolism and transport. Ignatius reports that synthesis and accumulation of apolipoprotein E increases in the distal segment of the damaged nerve. Probably this protein plays a role in the degradation of myelin sheet rich in lipids and is useful for incorporation of degradation products into membranes of newly formed axons ${ }^{4,16,33}$. Since, we identified in electrophoretograms of extracts from predegenerated nerves two fractions with molecular weights similar to apolipoprotein $\mathrm{E}-36.0 \mathrm{kDa}$ and $38.4 \mathrm{kDa}$, we assume that the above hypothesis is likely to be true. 
Table 2. Fractions with different molecular weight and $\mathrm{pH}$ range found in 2D-PAGE of postmicrosomal fractions from nonpredegenerated rat sciatic nerves.

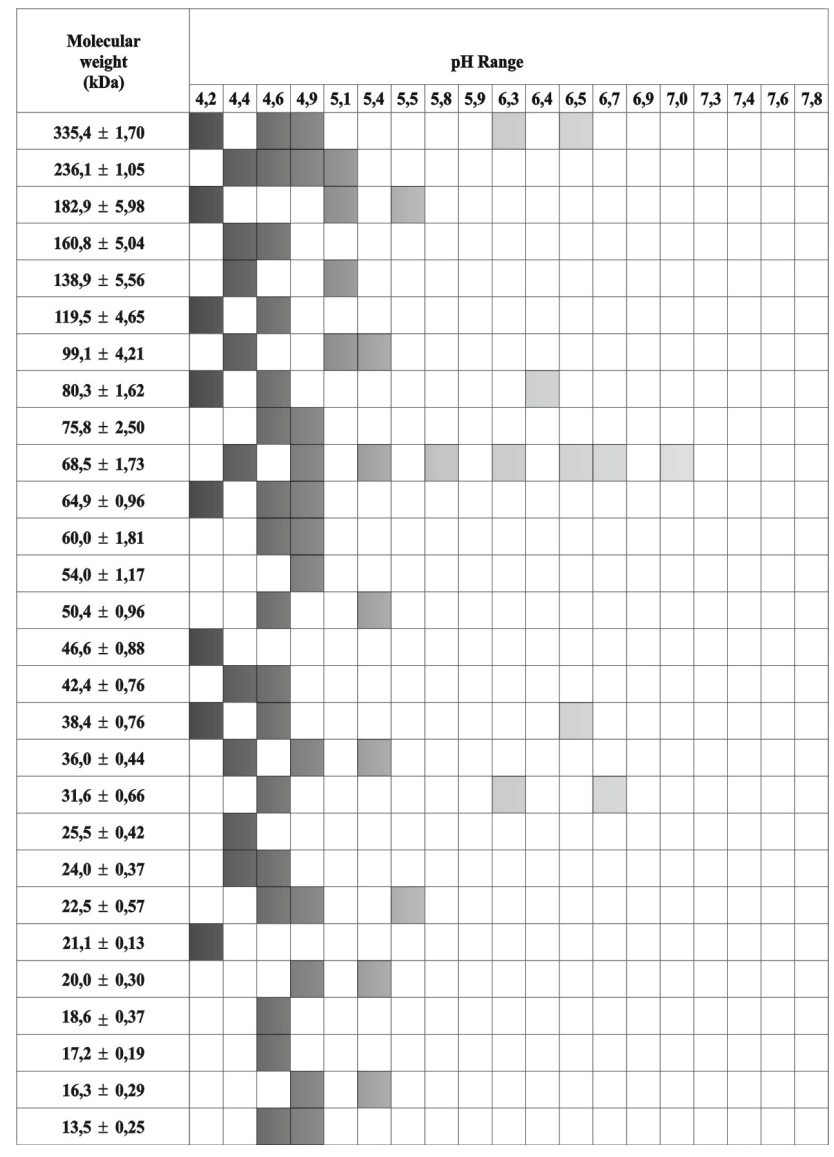

After analysis of electrophoretograms, two further fractions - 42.4 kDa and 46.6 kDa were the focus of our attention. These fractions in extracts from predegenerated nerves contained a large number of subfractions with very wide $\mathrm{pH}$ range $(42.4 \mathrm{kDa} \mathrm{pH}=4.4-7.4 ; 46.6$ $\mathrm{kDa} \mathrm{pH}=4.4-7.3)$. Presumably proteins known as GAPs (growth associated proteins) are located within the discussed range. GAPs are involved in the elongation of neuronal processes. After axotomy, synthesis of GAP-43 is especially increased. A molecular weight of GAP-43 is about $43 \mathrm{kDa}$. GAP-43 is considered as the marker of regeneration, because high expression of this protein takes place in growing axons of young animals and then is reduced in adults. The repeated increase of this protein expression occurs after breaking continuity of the nerve. GAP-43 is responsible for the polymerisation of actin ${ }^{18}$. Recently, GAP-43 has also been implicated in the regulation of synaptic transmission and plasticity in long-term potentiation $^{15}$.

Structural elements of cytoskeletal microtubules - $\alpha$ and $\beta$ tubulin (53 kDa, $55 \mathrm{kDa}$ ) and MAPs protein $(30 \mathrm{kDa})$ are probably among fractions with a molecular weight from $25.5 \mathrm{kDa}$ to $50.4 \mathrm{kDa}$. Phosphorylated forms of MAP1B participate in regeneration in the peripheral
Table 3. Fractions with different molecular weight and $\mathrm{pH}$ range found in 2D-PAGE of postmicrosomal fractions from predegenerated rat sciatic nerves.

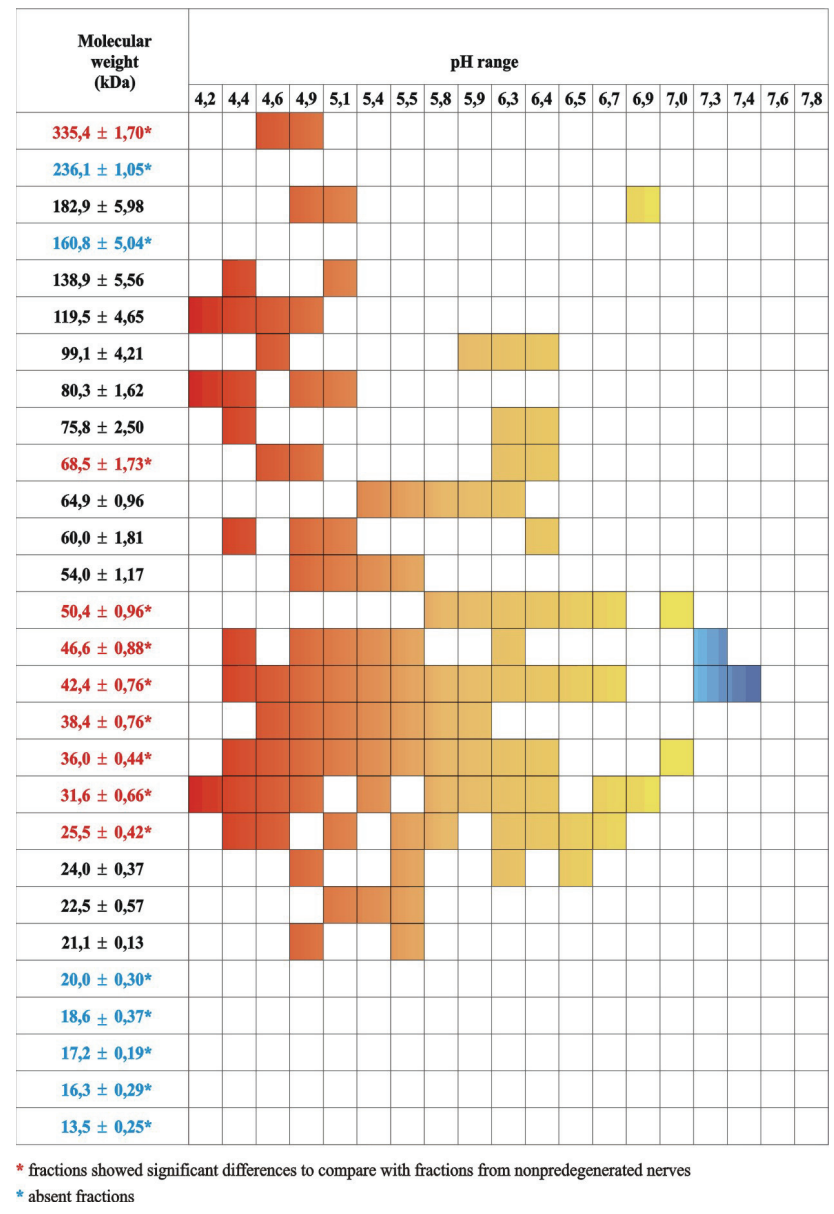

nervous system, being responsible for dynamic the character of microtubules ${ }^{36}$.

One of two fractions which have shown statistically significant decrease in the number of subfractions compared with extracts from nonpredegenerated nerves is fraction $68 \mathrm{kDa}$. (Tab. 2 and 3; Fig. 1) Molecular weight of $\mathrm{L}$ subunit of neurofilaments is about $57-70 \mathrm{kDa}$ and it is possible that one of the reasons for the absence of $68 \mathrm{kDa}$ proteins is degradation of this neurofilaments subunit ${ }^{37}$. Bignami and co-workers, analyzing Wallerian degeneration in the optic and sciatic nerves observed that proteins with molecular weights of about $72 \mathrm{kDa}$ and 150 $\mathrm{kDa}$, and which build neurofilaments, were not detected two weeks after the beginning of the degeneration ${ }^{2}$.

We observed lack of fractions $160.8 \mathrm{kDa}$ and $236.1 \mathrm{kDa}$ and statistically significant decrease in the number of the subfractions in $335.4 \mathrm{kDa}$ fraction. (Tab. 2 and 3 ) Subunites of rats neurofilaments - $M$ and $H$ have molecular weights 110-160 kDa and 160-210 kDa and probably they break up into proteins with lower molecular weight seven days after transection ${ }^{13,30}$. We assume that this is the reason that fractions $160.8 \mathrm{kDa}$ and $236.1 \mathrm{kDa}$ are not detected in electrophoretograms.

We should to remember, that in extracts from pre- 
degenerated peripheral nerves, beside known proteins - the neuron degradation products or neurotrophic factors, there are probably also some completely new proteins. Chakraborty and co-workers found that in the distal segment of the damaged rat sciatic nerve proteins underwent posttranslational modifications. This process is characteristic for proteins with molecular weight from 80-90 kDa, 53-66 kDa, 22-46 kDa and $17 \mathrm{kDa}$, with isoelectric points from 5.0 to 7.9 (Ref. ${ }^{5-7}$ ). Because of this modification the properties of new proteins are changed and may become favourable for supporting outgrow of the damaged nerve fibres.

In conclusion, the results of the present study demonstrate that the most intensive changes in protein composition of postmicrosomal fraction were observed in proteins between $25.5 \mathrm{kDa}$ and $68 \mathrm{kDa}$. In extracts from predegenerated nerves fractions below $21.1 \mathrm{kDa}$ (13.5 kDa, 16.2 kDa, 17.2 kDa, 18.6 kDa, 20.0 kDa) and fractions $160 \mathrm{kDa}$ and $266.1 \mathrm{kDa}$ these changes were absent. Among fractions described above, we should look for a factor or a combination of factors intensifying neurotrophic activity of extracts from predegenerated nerves. Identification of these molecules will help us to develop new strategies leading to the restoration of both structure and function of the damaged mature CNS.

\section{REFERENCES}

1. Agius E, Cochard P. Conparison of neutite outhgrowth induced by intack and injured sciatic nerves: a confocal and functional analysis. J Neurosci 1998; 18:328-38.

2. Bignami A, Dahl D, Nguyen BT, Crosby CJ. The fate of axonal debris in Wallerian degeneration of rat optic and sciatic nerves. Electron microscopy and immunofluorescence studies with neurofilament antisera. J Neuropathol Exp Neurol 1981; 40:537-50.

3. Bradford MM. A rapid and sensitive method for the quantation of microgram quantities of protein utilizing the principle of proteindye bding. Anal Biochem 1976; 72:248-54.

4. Cameron BM, VanderPutten DM, Merril CR. Preliminary study of an increase of a plasma Apolipopriten E variant associated with peripheral nerve damage. Spine 1995; 20:581-90.

5. Chakraborty G, Ingoglia NA. N-terminal arginylation and ubiquitin-mediated proteolysis in nerve regeneration. Brain Res Bull 1993; 30:439-45.

6. Chakraborty G, Leach T, Zanakis MF. Posttranslational protei modification by polyamines in intact and regenerating nerves. $\mathrm{J}$ Neurochem 1987; 48:669-75.

7. Chakraborty G, Yu M, Luo D, et al. Amino acid modification of proteins in regenerating sciatic nerves of rats. J Neurosci Res 1990; 25:503-10.

8. Chen DF, Tonegawa S. Why do mature CNS neurons of mammals fails to re-establish connections following injury - functions of Bcl2. Cell Death Differ 1998; 5:810-22.

9. Date I, Yoshimoto Y, Miyoshi Y, et al. The influence of donor age on congrafting of adrenal medulla with pretransected peripheral nerve. Brain Res 1993; 624:233-38.

10. Fawcett JW, Geller HM. Regeneration in the CnS: optimism mount. Trends Neurosci 1998; 21:179-80.

11. Gao H, Wang J, Zhang W, et al. Reconbinant adenovirus carrying cell line-derived neurotrophic factor gene protect midbrain dopaminergic neurons in mice. Beijing Da Xue Bao 2003; 35:25660 .

12. Gołka B, Lewin-Kowalik J, Święch-Sabuda E, et al. Predegenerated peripheral nerve grafts rescue retinal ganglion cells from axotomyinduced death. Exp Neurol 2001; 167:118-25.
13. Hirokawa N, Glicksman MA, Willard MB. Organization of mammalian neurofilament polypeptides within the neuronal cytoskeleton. J Cell Biol, 1984; 98:1523-36.

14. Horner PJ, Gadge FH. Regenerating the damaged central nervous system. Nature 2000; 407:963-70.

15. Hulo S, Alberi S, Laux T, Muller D, Caroni P. A point mutant of GAP-43 induces enhanced short-term and long-term hippocampal plasticity. Eur J Neurosci 2002; 15:1976-82.

16. Ignatius M, Skene JHP, Muller HW, Shooter EM. Examination of a nerve injury-induced, $37 \mathrm{kDa}$ protein: purification and characterization. Neurochem Res 1987; 12:967-76.

17. Ingoglia NA, Chakraborty G, Yu M, et al. Proteins isolated from regenerating sciatic nerves of rats form aggregates following posttranslational amino acid modification. J Mol Neurosci 1991; 2:18592.

18. Ju WK, Gwon JS, Park SJ, et al. Growth-associated protein 43 is up-regulated in the ganglion cells of the ischemic rat retina. NeuroReport 2002; 13:861-65.

19. Kaech S, Ludin B, Matus A. Cytoskeletal plasticy in cells expressing neuronal microtubule-associated protens. Neuron 1996; 17:1189-99.

20. Kordower JH, Fiandaca MS, Notter MFD, et al. NGF-like trofic support from peripheral nerve for grafted rhesus adrenal chromaffin cells. J Neurosurg 1990; 73:418-28.

21. Kotulska K, Lewin-Kowalik J, Larysz-Brusz M, et al. Bcl-2 Deficiency Deprives Peripheral Nerves of Neurotrophic Activity Against Injured Optic Nerve. J Neurosci Res 2003; 72:846-52.

22. Larysz-Brysz M., Lewin-Kowalik J, Górka D, Wolwender K. Peripherial nerve extracts change their neuroprotective activity upon CNS neurites after NGF blockade. Acta Neurobiol.Exp 2001; 61, 5th International Congress of the Po p. 210[17.11].

23. Larsson E, Mandel RJ, Klein RL, et al. Supression of insult-induced neurogenesis in adult rat brain by brain-derived neurotrophic factor. Exp Neurol 2002; 177:1-8.

24. Lewin-Kowalik J. Próby wzbudzenia regeneracji w ośrodkowym układzie nerwowym dorosłych szczurów. Ann Acad Med Siles Katowice. Praca habilitacyjna 1993.

25. Lewin-Kowalik J, Barski JJ, Krause M, et al. Neurotrophic effect of submicrosomal fractions obtained from predegenerated nerves. Restor Neurol Neurosci 1994; 7:71-8.

26. Lewin-Kowalik J, Górka D, Larysz-Brysz M, et al. Purified extracts from short-time-predegenerated rats' sciatic nerves promote the regrowth of injured hippocampal neurites. Acta Physiol Hung 1997/98; 85:325-34.

27. Lewin-Kowalik J, Sieroń AL, Barski JJ. Współczesne poglądy na rolę czynnika wzrostu nerwu oraz innych cząsteczek o udowodnionym działaniu neurotroficznym. Post Hig Med Dośw 1992; 46:497-519.

28. Lewin-Kowalik J, Sieron AL, Krause M, et al. The influence of peripheral nerve grafts predegeneration stage on the regrowth of hippocampal injured neurites and concominant changes in submicrosomal fractions proteins of grafts. Acta Physiol Hung 1992; 79:219-31.

29. Lewin-Kowalik J, Sieroń AL, Krause M, et al. Time-dependent regenerative influence of predegenerated nerve grafts on hippocampus. Brain Res Bull 1992; 29:831-35.

30. Liem RKH, Hutchison SB. Purification of invidual components of the neurofilament triplet: Filament assembly from the 7000-dalton subunit. Biochemistry 1982; 21:3221-26.

31. Marcol W, Kotulska K, Święch-Sabuda E, Larysz-Brysz M, Gołka B, Górka D, Lewin-Kowalik J. Regeneration of sciatic nerves of adult rats induced by extracts from distal stumps of pre-degenerated peripheral nerves. J Neurosci Res 2003; 72:417-24.

32. Messersmith DJ, Fabrazzo M, Mocchetti I, et al. Effects of sciatic nerve transplants after fimbria-fornix lesion: examination of the role of nerve growth factor. Brain Res 1991; 557:293-297.

33. Nathan BP, Jiang Y, Wong GK, et al. Apolipoprotein E4 inhibits, and apolipoprotein E3 promotes neurite outgrowth in cultured adult mouse cortical neurons through the low-density lipoprotein receptor-relatedprotein. Brain Res 2002; 928:96-105.

34. O'Farrell P H. High resolution two dimensional elektroforesis of proteins. J Biol Chem 1975; 250:4007-21. 
35. Rabchevsky AG, Smith GM. Therapeutic interventions following mammalian spinal cord injury. Arch Neurol 2001; 58:721-6.

36. Ramon-Cueto A, Avila J. Two modes of microtubule-associated protein 1B phosphorylation are differentially regulated during peripheral nerve regeneration. Brain Res 1999; 815:213-26.

37. Sotelo JR, Benech CR, Kun A. Local radiolabeling of the $68 \mathrm{kDa}$ neurofilament protein in rat sciatic nerves. Neurosci Lett 1992; 144:174-6.

38. Southern EM. Long range periodocities in mouse satelite DNA. J Mol Biol 1975; 94:51-69.
39. Stichel CC, Müller HW. Experimental strategies to promote axonal regeneration after traumatic central nervous system injury. Prog Neurobiol 1978; 55:119-48.

40. Torigoe K, Tanaka H-T, Takahashi A, Awaya A, Hashimoto K. Basic behavior of migratory Schwann cells in peripheral nerve regeneration. Exp Neurol 1996:137, 301-8.

41. Wray W, Boulikas T, Wray UP, Hanock R. Silver staining of proteins in polyacrylamide gels. Analyt Bioch 1981:118-97. 